\title{
DISTRIBUTION OF CORAL COMMUNITIES ON REEF SLOPES IN THE MASCARENE ARCHIPELAGO, INDIAN OCEAN
}

\author{
by \\ GERARD FAURE ${ }^{1)}$
}

\begin{abstract}
Three zones and sic "horizons" are defined and described on the basis of topographic elements, growth forms of corals, generic and specific diversity of scleractinians and associated fauna and flora - : Spurs and grooves zone of coral-built morphogenesis ("horizon superieur" 0-5m, "horizon intermediaire" 5-15m, "horizon inferieur" 15-20m); Spurs and grooves of volcanic morphogenesis 20-25m; Volcanic flagstone ("horizon superieur" 25-30m, "horizon moyen" with sponges and corals, 30-35m, "horizon inferieur" with gorgonians and antipatharia $35-50 \mathrm{~m}$ ). A total of 98 species belonging to 58 genera were collected on reef slopes. It was found that there is a successive increase in generic and specific diversity from the upper part (36 species), to 20 meters ( 63 species), related to the decrease of exposure to wave action. The decrease in the number of species from 25 ( 54 species) to 50 meters ( $\leq 18$ species), proves that light becomes a limiting factor below $25-30 \mathrm{~m}$. Nevertheless, sedimentation effects, biological competition (algae, sponges, alcyonarians....) and other factors are very significant in determining community structure of corals.

A comparative study (quantitative and qualitative distribution, zonation) with other localities is suggested as conclusion.
\end{abstract}

\section{MORPHOLOGY OF THE CORAL REEFS AND THE OUTER SLOPES OF THE MASCARENE ARCHIPELAGO.}

The Mascarene Archipelago is composed of three volcanic islands : Reunion, Mauritius, Rodrigues, more or less surrounded by coral reefs. It is situated in the western Indian Ocean near Madagascar, between longitudes $55^{\circ} 32^{\prime}-63^{\circ} 30^{\prime}$, latitudes $21^{\circ} 7^{\prime}-19^{\circ} 40^{\prime}$. The present aspect of the outer slopes of the Mascarene Archipelago coral reefs owes as much to geology, littoral and reef morphology, as to general and local environmental peculiarities. We shall summarize the present knowledge of the general morphology and features of the outer slope in the Mascarene area from the recent works of : PICHON $(1967,1971)$, FA-URE \& MONTAGGiOni (1970,1971 a, 1971 b, 1975), MONTAGGIONI (1970, 1972, 1974, 1975), FAURE (1974, 1975), ROBERT (1975), BATTISTINI et al. (1975).

1) Station Marine d'Endoume, Marseille (Antenne de la Reunion, B.P.5 Ste-Clotilde-97490, Reunion Ocean Indien). 


\section{GERARD FAURE}

\section{CORAL REEF UNITS}

Five main coral reef units have been defined :

1) The reef-banks, corresponding to submerged volcanic flagstone, from 0,5 to $5 \mathrm{~m}$ below low tide. The juction with the neighbouring sandy bottom is either gradually realized through a "spurs and grooves zone of volcanic morphogenesis", or takes the form of a steep wall, or again of a "volcanic morphogenesis buttress". Reef banks are com mon in Reunion and Mauritius, and scarce in Rodrigues.

2) The reef platforms are formed in the same way as the reef banks by coastal volcanic flow in shallow waters. The junction with the littoral is realized without any boat channel or "lagoon". The upper part of the outer slope from 0 to $15-20 \mathrm{~m}$, is composed of "spurs or buttresses of coral-built morphogenesis". These reef aspects are common in Reunion, Mauritius and Rodrigues.

3) Fringing reefs. Contrary to the previous areas, the fringing reefs are distinguished by a morphological and biological zonation, either across the reef flat, or on the outer slope. They are separated from the shore by a trough ("lagoon", boatchannel). Most of the coral units in the Mascarene region are fringing reefs.

4) Barrier-reefs, are abserit from the Mascarene shores, except in Mauritius: Barrier-reef of Mahebourg. This barrier-reef is 400 to $600 \mathrm{~m}$ wide, $9 \mathrm{~km}$ long and isolated from the shore line on 3 to $5 \mathrm{~km}$ by means of channels (1,5 to $2 \mathrm{~km}$ wide, 15 to $30 \mathrm{~m}$ deep) connected to the open sea through two large passes.

5) Inner-reefs. These coral reef tracts lie near the shore line in the S.E. part of Mauritius, from Mahebourg to Grande Riviere Sud-Est. They are composed of several units separated from each other by channels 200 to $400 \mathrm{~m}$ wide, $10-15 \mathrm{~m}$ deep, roughly perpendicular to the shore. The outer slope of these reef formations shows a zonation paralleling that of the sheltered reef outer slope (fringing and barrier reefs).

\section{THE OUTER SLOPES}

Three main zones follow one another along the slope:

1) The coral-built morphogenesis zone. It is the upper part of the slope from 0 to $20 \mathrm{~m}$, generally built by coral, and having organic crest. According to the hydrodynamic water conditions, three morphological aspects will be defined. 


\section{DISTRIBUTION OF CORAL COMMUNITIES}

a) Spurs and grooves of coral morphogenesis aspect. Made of coral-built crest, the spurs are roughly perpendicular to the reef front, and alternate with grooves whose sidewalls slope more or less sharply. This aspect characterizes the windward reefs and areas exposed to rough sea, as well as expanding areas. (East to south-west of Rodrigues, west and south-west of Reunion, east and south-east of Mauritius).

b) Buttresses of coral morphogenesis aspect. Along the shelter ed areas, the spurs and grooves zone is hardly distinguishable. This part corresponds to an abrupt forewall, cut by narrow and vertical grooves which extends to a depth of $10-15 \mathrm{~m}$. This aspect characterizes ba lanced areas (N. of Rodrigues, N-W. of Reunion, W. of Mauritius).

c) Coral flagstone aspect. It is a feature of organic origin, slop ing slightly and regularly towards the open sea formed, as a result of anastomosis and junction between the spurs and between the grooves. It corresponds to subterminal coral activity (N.NE. Mauritius).

From these topographic elements and on the basis of the coral distribution (growth forms, generic specific diversity, abundance-dominance coefficient) three horizons are defined in this part of the slope: "L'horizon superieur" from 0 to $5 \mathrm{~m}$; "L'horizon intermediate" from 5 to $15 \mathrm{~m}$; "L'horizon inferieur" from 15 to $20 \mathrm{~m}$.

2) Zone of volcanic morphogenesis. At about $20 \mathrm{~m}^{\wedge}$ the coral-built structures tend to disappear and were replaced by a zone of volcanic morphogenesis. The main features of this zone are due to the initial topographic frame. These features resemble surfaces of lava flows cut by cooling fissures or breaks. The principal characters of the volcanic morphogenesis zone are : "spurs and grooves of volcanic origin"; "buttresses of volcanic morphogenesis". These structures appear rarely in shallow water, except in the north of Reunion. In many instances they are restricted to the area between the preceding zone, and the volcanic flagstone zone (lower sloping platform).

3) Volcanic flagstone zone (lower sloping platform). This feature represents the deeper part of the outer slope $(25$ to $50 \mathrm{~m})$. It gently slopes towards the open sea and shows a few slight topographic irregularities resulting from the faster growth of some corals or volcanic structures. Its extent is very uncertain in Mauritius and Reunion, and in many instances, it disappears under the outer sandy spread at a depth of $30 \mathrm{~m}$ in Rodrigues. Three "horizons" are defined, chiefly on the basis of coral distribution and associated fauna and 
flora : "L'horizon superieur" from 25 to $30 \mathrm{~m}$, where corals are dominant; "L'horizon moyen" from 30 to $35 \mathrm{~m}$ with corals and sponges; "L'horizon inferieur" $35-50 \mathrm{~m}$ with gorgonians and antipatharia.

\section{SCLERACTINIAN CORAL DISTRIBUTION ON THE REEF SLOPES}

\section{Coral-built morphogenesis zone (Zone 1) : 0-20m}

The distribution, abundance-dominance and significance of species situated in this zone are chiefly connected with the variations of strength of water movement. According to PICHON (1973) and Ro -SEN (1971, 1975), the main coral communities are associated with a double gradient of decreasing water movement, from the reef front to the reef flat and back-reef areas (horizontal gradient), and from the reef front towards and along the outer slope (vertical gradient). These authors underline a physiognomic connection between outer slope communities and reef flat communities, on the basis of growth forms due to the two hydrodynamic gradients. Yet, on the basis of the specific distribution and specific affinities, there is no connection between the upper part of the slope and the reef flat. The specific affinity of species situated in the spurs and grooves of the coral morphogenesis zone is stronger with those of the deeper part of the slope, than with those of the reef front and reef flat Thus $93 \%$ and $63 \%$ of the species counted in the "horizon superieur" $(0-5$ $\mathrm{m})$ are respectively present in the "horizon intermediaire" $(5-15 \mathrm{~m})$ and in the "horizon inferieur" (15-20m). These precentages are 53\% and less than $30 \%$ for the reef front and reef flat, where however the hydrodynamic components are alike. Other factors such as emersion, sedimentary transport or deposit, biological competition (mainly both the calcareous and non calcareous algae) have an effect on the reef flat and exclude many well adaptated rough water or tolerant species, otherwise present on the outer slope. 1) The "horizon superieur" $0-5 \mathrm{~m}$ (Fig. 1a). In the uppermost part of the slope, both coral coverage (40\%) and number of species (36) are relatively reduced. Of that last number, 34 species spread to the "horizon intermediaire", 24 to the "horizon' inferieur" 19 to the emerging part of the reef front. Owing to this fact, there is no "exclusively characteric" species in the present biotope. However some of those whose abundance-dominance is greater here than in the neighbouring biota are considered as being or indicator species: - Rough water indicator species: Acropora danai, Acropora corymbosa, Pocillopora brevicomis setchelli, Montastrea annuligera, Psammocora haimiana and the hydro-coral Millepora platyphylla. 


\section{DISTRIBUTION OF CORAL COMMUNITIES}
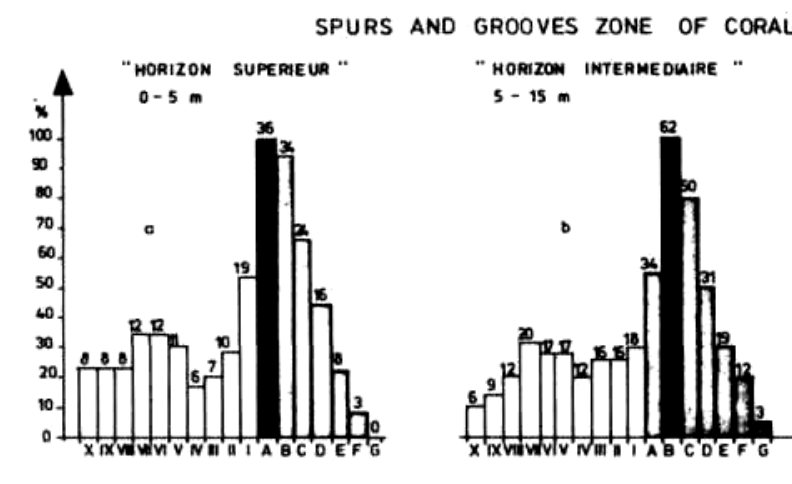

MORPHOGENESIS

5 - $15 m$
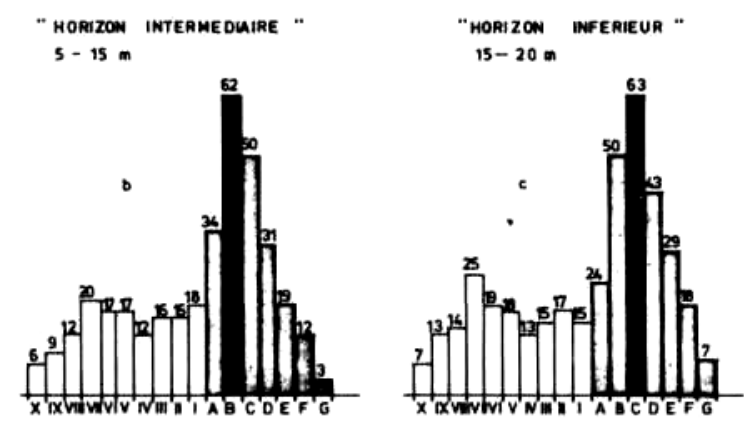

VOLCANIC

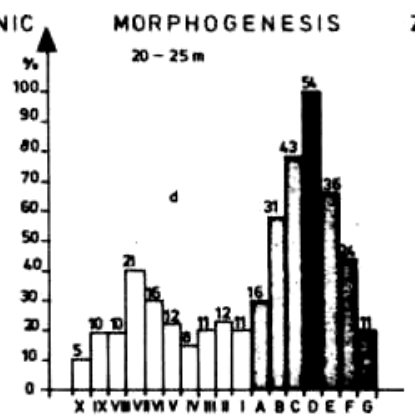

ZONE
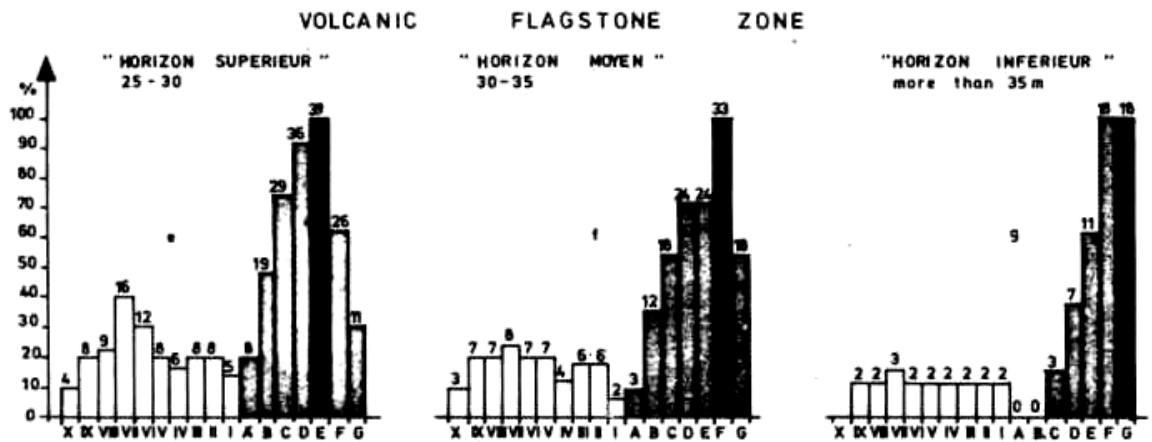

Figure 1. Number of coral species as function of different zones and horizons on the outer slopes of Mascarene reefs (Black bars); their extension (number of species and percentage), in the neighbouring biota: Outer slope (grey bars), reef flat and lagoon (white bars), list of biota: A. - Spurs and grooves of coral morphogenesis, "Horizon superieur", B. - Spurs and grooves of coral morphogenesis, "Horizon intermediate", C. - Spurs and grooves of coral morphogenesis, "Horizon inferieur", D. Volcanic morphogenesis zone, E. - Volcanic flagstone, "Horizon superieur", F. - Volcanic flagstone, "Horizon moyen", G. - Volcanic flagstone, "Horizon inferieur". I. - Spur upper platform, II. Outer reef flat, III. - Inner reef flat (compact reef flat), IV. Inner reef flat (reef flat with transverse stripes), V. - Lagoon, VI. - Inner slope, VII. - Pass, VIII. - Reef pool, IX. - Creak and outfall, X. - Inner reef. 


\section{GERARD FAURE}

- Calm water indicator species: Acropora pharaonis, A. hyacinthus, A. cf hemprichi, Synarea iwayamaensis, Herpolitha limax.

Nevertheless more than half the species found in the uppermost part of the slope are non significant species or species with wide distribution whose abundance-dominance is not higher than in other biota of the reef slope: Leptoria phrygia, Platygyra daedalea, Montipora verrucosa, Stylophora pistillata, S. mordax, Pocillopora verrucosa, Favia pallida, F. speciosa, Favites virens, Goniastrea retiformis, Goniastrea pectinata ....

- Finally the overhanging sidewalk of coral-built spurs are characterized by a sharp decrease in light and present a sciaphilic community where Tubastrea aurea and the Stylasteridae Distichopora violacea are domi nant.

2) The "horizon intermediate" $5-15 \mathrm{~m}$ (Fig.lb). This part coin cides with that of high coral diversity $(62$ species $)$ and coverage $(\geq 70 \%)$ owing to the increase of wave action. Yet most of the scleractinian species (34/36) of the preceding horizon remain here and suggest that hydrodynamic activity prevails on other ecological factors.

Amongst 28 species which appear in this area, only one seems to be dependent upon the middle horizon: Culicia cuticula whose requirements are closed to the sciaphilic species of the upper part. The other coral species reach the lower part of the slope: 16 in the "horizon inferieur" and volcanic morphogenesis zone, 11 in the lowest area (volcanic flagstone) where they have a weak abundance-dominance with the exception of Pachyseris speciosa and Echinophyllia aspera.

On the basis of qualitative distribution, beside the rough water indicator species from the preceding horizon, the corals belong to two groups according to the slope of the substratum. Table-shaped and terrace forming species $s_{t}$ are dominant on the top of the spurs especially: Acropora reticulata, A. hyacinthus mixed with numerous little brain and massive colonies: Favia pallida, F. speciosa, Plesiastrea versipora, Hydnophora microconos. ... and branched forms: Stylophora pistillata, P.verrucosa.

On the sidewall of grooves large encrusting and cascade-shaped colonies are dominant. The percentage coverage is large but the number of species is scarce due to inhibition of growth of other forms. The most important species are: Echinopora gemmacea, Leptastrea purpurea, Pa-vona explanulata, Agariciella ponderosa and locally, Pachyseris speciosa, Echinophyllia aspera.

Sometimes calcareous algae (Lithophyllum spp.) and alcyonarians (see facies) take the place of corals.

3) The "horizon inferieur" $-15-20 \mathrm{~m}$ (Fig. 1c). The number of species (63) and coverage by corals (60\%) are similar to the preceding part. Contrary to the two preceding biota, coral species here stretch to 


\section{DISTRIBUTION OF CORAL COMMUNITIES}

the upper parts of the slope (average 59\% for both the "horizon superieur" and the "horizon intermediaire") just as in the two following deeper biota (volcanic morphogenesis zone and the "horizon superieur" of the volcanic flagstone: (average 58\%). In this respect, the present reef division seems to be a transitional area between the lesser depths of the slope (under the preponderance of hydrodynamic actions) and the deeper parts (under the dominance of light factor). The results of a qualitative studies point in the same direction; they show:

- The persistence of corals from the "horizon superieur", except rough water indicator species.

- The existence of a large number of non significant species coming from the "horizon intermediaire" to the volcanic flagstone such as: Podabacia Crustacea, Symphyllia recta, Porites somaliensis, Favia speciosa, F. pallida

- The appearance of a small number of preferential scleractinians from the volcanic morphogenesis zone and volcanic flagstone zone with a lower abundance-dominance such as: Coscinarea monile, Cycloseris cyclolites, Echinophyllia aspera, Pachyseris speciosa, Oxypora lacera.

-A last group contains species whose ecological requirements are strict (average of light and water agitation) as: Montipora tuberculosa, Pavona (Pseudocolumnastrea) pollicata, Goniopora lobata, G. tenuidens, Plesiastrea versipora, Alveopora mortenseni.

\section{Zone of volcanic morphogenesis (spurs and grooves of structural mor- phogenesis - Zone 2) - 20-25 m (Fig. 1d)}

The study of scleractinian coral distribution shows that the present zone is a mixed zone. However its originality comes from the start of a decrease in the number of species ( 54 species, coverage $\leq 50 \%$ ) owing to a non optimal ecological environment. Species belong to three groups:

below

Species with wide distribution are still numerous here, and yet,

this depth most of them disappear: Stylophora mordax, Pocillopora verrucosa, Acropora hyacinthus, A. reticulata, Pavona clavus, Pavona explanulata, Agariciella ponderosa . . . .

-On the other hand a second group contains some characteristics species from the volcanic flagstone, like Blastomussa merleti, Pocillopora eydouxi, Acropora granulosa, Horastrea indica, Turbinaria peltata, Parascolymia sp.

- Some corals seem to be preferential species of the spurs and grooves of the volcanic morphogenesis zone: Lobophyllia hemprichi, Pachyseris rugosa, Turbinaria cf. porcellana, Fungia (Ctenactis) scutaria, Oulophyllia crispa, Coscinarea monile. 


\section{GERARD FAURE}

The volcanic flagstone zone (Lower sloping platform - Zone 3): 25 to. 50-60 m).

Between 25 and 50-60 meters there is a lower sloping platform of volcanic morphogenesis covered with a thin coral layer. According to topographical diversity, and local environmental factors, the aspect of the platform is extremely variable from windward areas to leeward slopes, as well as between the three islands (MONTAGGIONI 1974, FAURE \& MONTAGGIONI 1975).

The main characteristic of the flagstone is the progressive decrease in the number of coral species from the upper part ("horizon superieur": 38 species) to the lower part ("horizon" with gorgonians and antipatha-ria: 18 species).

The decrease in diversity and coverage with increase in depth is generally attributed to the decrease of light intensity. Another aspect of the progressive reduction in illumination is the progressive substitution of sponges, gorgonians, antipatharia for corals. However decrease of light can not explain the severe competition between locally dominant algae (E. of Mauritius) from the higher part (zone 1) and the junction between the lower sloping platform and the outer sandy spread. Generally, owing to the roughness of water in the surf zone of windward reefs, coral development is usually poor. Calcareous algae (reef front) and fleshy ben-thic algae (outer reef flat) outgrow corals. Nevertheless in spite of its standing below a $15-20 \mathrm{~m}$ depth, swell has no "mechanical" effect on the coral activity and no action on the lower flagstone coral communities. Anyhow in these lower depths swell action cannot explain the bionomic dissymmetry between eastern and western reef areas in Mauritius (percent coral coverage on the west side from $30-60 \mathrm{~m}$ : $>80 \%$, algal cover $10 \%$, other $10 \%$, coral cover east side at the same depths $:<10 \%$, algae $80 \%$ ). On the other hand, owing to the fact that both the western and eastern reef areas are surrounded by the same oceanic waters, it is only fair to think that the physical and chemical water components are the same all around island. Also there will not be any major disparity in light intensity and radiant energy. A possible explanation for this phenomenon lies in the difference of the precipitations between the two casts. The abundant precipitations on the humid east coast of Mauritius, feed a large hydrographic complex, liable to disturb the local marine water qualities (mainly enrichment in terrigenous elements and mineral salts) and to promote growth and dominance of algae.

1) The "horizon superieur" : 25-30 m (coral horizon) (Fig. $1 \mathrm{e}$ )

On the basis of qualitative coral distribution between this zone and the preceding one there are no important differences. More than $90 \%$ of the species recorded here are present in the volcanic morphogenesis zone. The degree of affinity with the lower parts of the slope are as 


\section{DISTRIBUTION OF CORAL COMMUNITIES}

follows : 60\% with the "horizon moyen" (sponges and corals horizon) and $30 \%$ with the deeper part ("horizon inferieur"). So, in spite of the fact that the spurs and grooves zone of volcanic morphogenesis, and the flagstone, belong to different geomorphological entities, these two biota have an important specific affinity suggesting that the coral communities of the "horizon superieur" of the platform is an impoverished facies of the preceding zone. Yet mainly on account of the specific morphological features of these two parts, and secondarily on account on the sharp decrease in diversity and coral coverage, we maintain that the "horizon superieur" has its own characters and individuality.

2)The "horizon moyen": $30-35 \mathrm{~m}$ (sponges and corals horizon)

(Fig. $1 \mathrm{f}$ )

Its principal feature is the decrease in coral-building activity (coverage 20\%). Corals compete with sponges and algae. Among sponges, Spirastrella inconstans, Spirastrella porosa, Axinella spp., Leucetta microraphis, Haliclona sp. are the. most common.

- Algae communities are very variable in their extent and composition (see facies). Some of them may be considered as preferential characte ristic species : Dictyopteris serrata, Spatoglossum asperum, Halymenia floresia, Halimeda spp

- Corals come from two different groups : The first group originates from zone 2 and upper part of the flagstone such as: Favites peresi ecomorph ( FAURE \& PICHON 1976), Echinopora gemmacea, Horastrea indica, Porites somaliensis, Acropora granulosa, Parascolymia sp., Turbinaria peltata, Echinophyllia aspera, Oxypora lacera, Pachyseris speciosa, Blastomussa merleti. The second comprises the exclusively characteristic species of the flagstone: Leptoseris fragilis, L. hawaiensis, L. columna, Leptoseris sp. Pectinia lactuca, Montipora of millepora, Tubastrea micrantha.

- Other species normally encountered in the deepest part of the leeward reef slope or lagoon areas are excluded from the windward slope at the same depths, but are restricted to the deepest parts as: Herpolitha Limax, Gyrosmilia interrupta Caulastrea tumida, Seriatopora hystrix.

- Many species independently of their initial specific shape and with the aim of drawing maximum benefit from light, show a characteristic morphology founded on flattening and spreading on the substratum. According to PICHON (1973), this phenomen yields the prevailing occurrence of encrusting and lamellar species largely lying on the substratum. Nevertheless this light adaptation frame exposes them to biological competition and to sediment effects.

3)The "horizon inferieur": $35 \mathrm{~m}$ (horizon with gorgonians and antipatharia) 
It is characterized by the large growth of gorgonians and antipatharia whereas corals are weakly present $(18$ species : coverage $5-10 \%)$. The most commom gorgonians are : Wrightella coccinea, Villogorgia ceylonensis, Junceella juncea, Lophogorgia thomassini, Muricella perramosa, Muricella rubrum, Ellisella bardadensis, Gorgonia umbellata, Paracis alba, Rumphella aggregata, Ellisella sp. Among antipatharia, some are exclusively characteristic species such as: Antipathes abies, A. reticulata, A. dichotoma. Other species are abundant both on the volcanic flagstone and on other zones: Antipathes myriophylla, Cirripathes anguina, Cirripathes spiralis. The seaweeds are locally abundant, but not different from those of the preceding horizon.

\section{FACIES}

The balance of ecological components can be locally disturbed by the preponderant action of one or several edaphic factors (roughness of wave action, currents, sediment deposits, water turbidity, sharp decrease of light ....). They cause an unbalance amongst scleractinian communities, and induce the advent of facies in which associated fauna and flora are dominant.

1)Alcyonarian facies

The alcyonarians are relatively abundant in the coral reef communities from 0 to $30 \mathrm{~m}$. At this last depth they are generally replaced by gorgonians and antipatharia. The greatest alcyonarian spread is observed both in the vicinity of topographical discontinuities such as, passes, outer and inner creeks, channels, whose main feature is to be travelled by water currents and on the outer slope surrounded by turbid water, where the percentage coverage is from 50 to $80 \%$. Three aspects can be defined on the outer slopes:

In the upper part of the spurs and grooves zone of coral built morphogenesis, the species mainly belong to the genus Cladiella as: Cladiella australis, C. ceylonica, C. hicksoni, C. krempfi.

In both the "horizon intermediate" and "horizon inferieur" of the same zone, Lobophytum and Sarcophyton are dominant: Lobophytum compactum, L. crassum, L. schoedi, L. sarcophytoides, L. batarum, Sarcophyton regulare, S. solidum, S. crassocaule, S. glaucum.

The lower parts (volcanic morphogenesis zone, volcanic platforms) are characterized by species belonging to the genus, Sinularia: S. densa, S. pedunculata, S. arborea, S. macropodia, S. hirsuta. Some other species have a large distribution from the reef front to the volcanic such as: Alcyonium aspiculatum, Sinularia polydactyla.

2)Free melobesian nodules (rodolithes) facies

Locally the volcanic flagstone is overlaid by coarse organogenous detritic material. The nodules spread out as often as favourable hydrodynamic 


\section{DISTRIBUTION OF CORAL COMMUNITIES}

activity (wave action, under currents, rip currents, wind currents) occurs. We have only few observations about melobesian nodules in the vicinity of the western Indian Ocean, except in Madagascar: ClAUSADE et al. (1971), THOMASSIN (1971), PICHON (1973), WEYDERT (1974) and BARNES et al. (1970), in the north of Aldabra.

In the Mascarene Archipelago the present facies shows two aspects: the first consists of more or less encrusted madreporarian chips discoid or flat shaped, comparable to "pseudo-nodules" (WEYDERT 1974). They are arranged as a trail perpendicularly to the reef front, or overlap the flagstone sedimentary hollows. The dissymmetrical thickness of the melobesian layer proves the poor possibilities of displacement of these nodules, and so they can be considered as hard substrata. In such agreement with that fact they generally serve as a support of scleractinian colonies such as Parascolymia sp., Echinophyllia aspera, Leptoseris spp., Turbinaria peltata ...

The second aspects consists of true nodules localised at the junction between the lower sloping platform and the outer sandy spread, in a direction parallel to the reef front, and in the flagstone hollows. They are of spherical or subspherical shape and their average of diameter is between 8 and $25 \mathrm{~cm}$. Their shape, the regularity of successive deposits of calcareous algae (Sporolithon spp.) around nuclei, and the fact that they are rarely colonized by scleractinians or other organisms, attest to their regular transfer under the effects of currents. They can be considered as soft bottom substrate.

3) Facies linked to decrease of light: facies with gorgonian and antipatharia (see communities of the volcanic flagstone) Algal facies*).

According to the depth two main aspects can be defined on the outer slope:

In the upper part $0-20 \mathrm{~m}$, the species chiefly belong to the genus Sargarsum. Some of them come from the reef front and outer reef flat, but the greatest part is restricted to the slope. On sheltered reefs, they compete with Asparagopsis sp. In the same environment, the sandy bottom of the grooves is planted with Udotea palmetta, Udotea argentea, Halimeda tuna, H. opuntia.

The lower parts (volcanic morphogenesis zone, volcanic flagstone) are characterized by very numerous species of algae in which: Spatoglossum asperum, Halymenia floresia, Halimeda platydysca, Titanophora sp., Galaxaura sp. are the most abundant. The other species belong to the genera: Padina, Dictyota, Dictyopteris, Botryocladia, Zonaria, Caulerpa.

\footnotetext{
*) Most of the samples are in course of identification by Dr Doty (University of Hawaii).
} 


\section{GERARD FAURE}

\section{CONCLUSIONS DISCUSSIONS}

\section{Definition and delimitation of the different zones}

Three zones and six "horizons" are defined on the basis of topographic elements, growth form of corals, and specific diversity, on the outer slopes of Mascarene reefs.

1) In the upper zone $(0-20 \mathrm{~m})$. the vertical distribution of major coral forms and scleractinian assemblages are controlled by the variation in strength of water movements:

- "horizon superieur" with robust ramose corals (Acropora danai), encrusting $6 x$ plate like forms (Millepora platyphylla), stout-branched forms (Pocillopora), massive (Faviids)

-"horizon intermediate" with Acropora spp. (staghorns, tabular), encrusting corals (Echinopora, Pavona).

-"horizon inferieur" where growth forms are mostly massive (Porites, Faviids)

This scheme may be applicable not solely to the Mascarene region (Table I). It is very close to Madagascar (PICHON 1964,1967,1973; and perpersonal observations), similar of those of Aldabra ( BARNES et al. 1971), Eilat (LOYA \& SLOBODKIN 1971, LOYA 1972). Seychelles (Rosen 1971). It presents some analogy with Pacific atolls such as Mururoa (CHEVALIER et al. 1969) and confirms the scheme suggested by ROSEN (1975) for the Indopacific area.

Furthermore PICHON (1973) using the Atlantic results of GOREAU (1959), LEWIS (1960), ROOS (1964), LABOREL (1967) and taking into account the identity of growth forms and hydrodynamic conditions, gives a very similar scheme for Madagascar and ROSEN zones (1975): upper part with Acropora palmata, Millepora alcicornis, Diploria sp., middle one, with Acropora cervicornis, lower part where growth forms are mainly massive. (Montastrea spp.).

2) The second zone $(20-25 \mathrm{~m})$. The spurs and grooves zone of volcanic morphogenesis is considered as a transitional zone on the basis of growth forms as well as specific diversity. Its specificity comes from its geomorphological features.

3) The lower sloping platform 25 to $50-60 \mathrm{~m}$. In spite of numerous recent investigations on the lower part of the outer slope, the knowledge of communities distribution and zonation between 25 to $50-60 \mathrm{~m}$ is generally fragmentary; either because it is the subject matter of provisional and incomplete monographs, or due to the limits of investigations by skin diving ( ROSEN 1975 ).

In the Mascarene Archipelago the zonation will be based essentially both on the decrease of coral communities and on its opposite the great expansion of associated fauna. In the same way, BARNES et al. (1971), in 
DISTRIBUTION OF CORAL COMMUNITIES

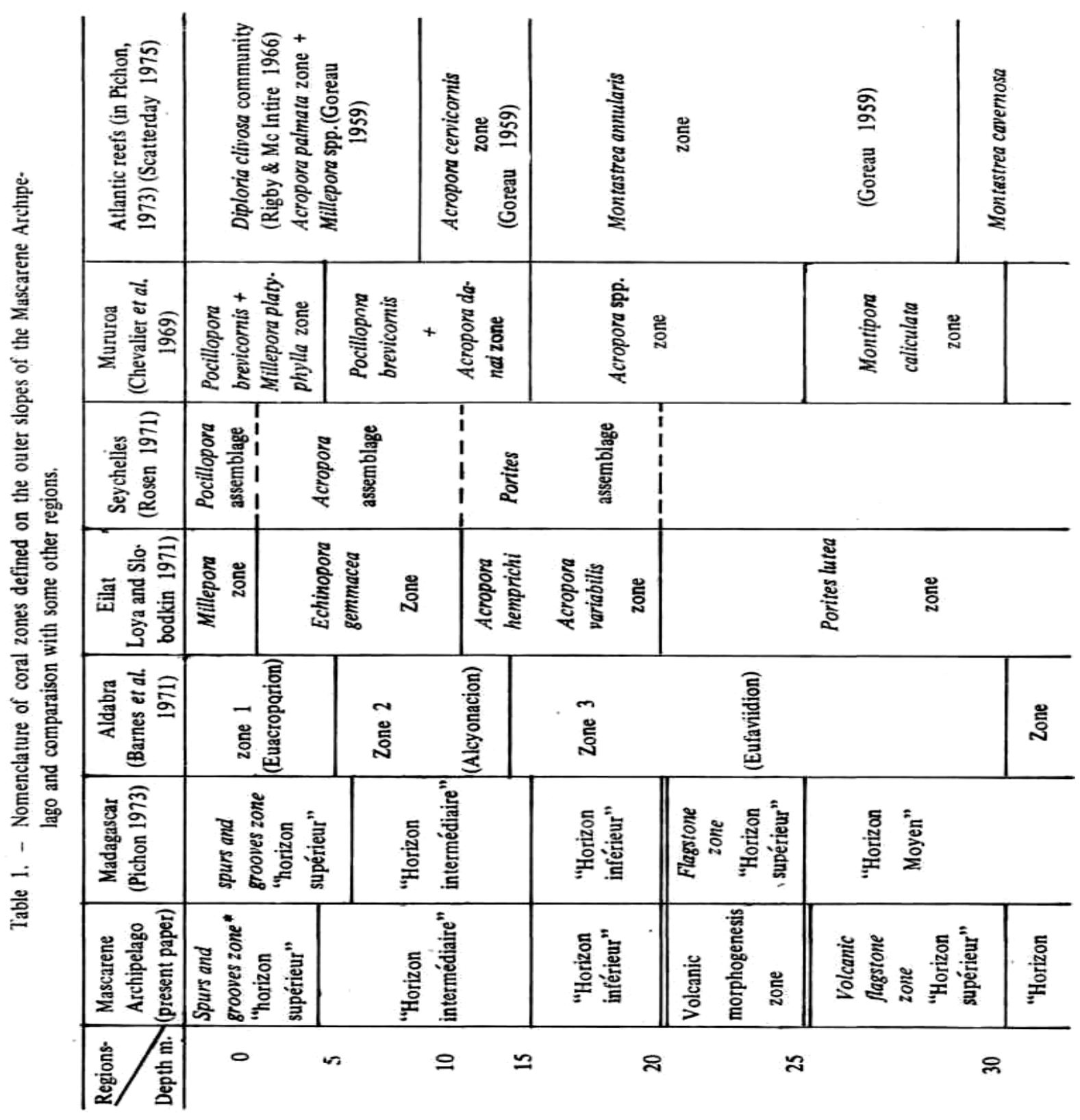




\section{GERARD FAURE}
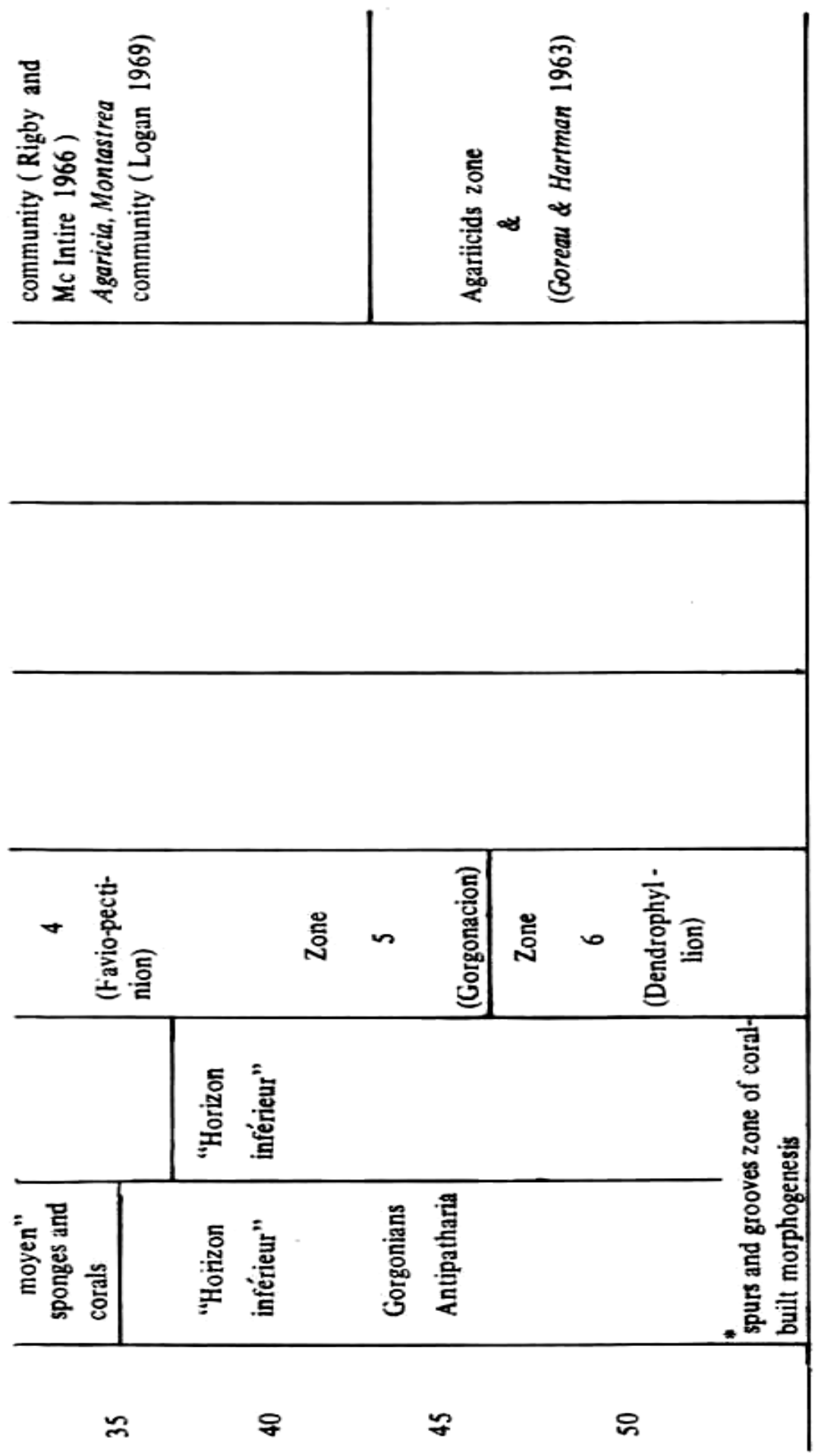
Aldabra define a "Gorgonacion zone" from 38 to 442 m; PICHON (1973) gives a complete and detailed check list of associated non scleractinian species (sponges, gorgonians, antipatharia, algae) whose abundance dominance is greatest between 30 to $50 \mathrm{~m}$, than that of corals.

From the scleractinian vertical distribution, this author suggests to name the lowest outer-slope part: "Zone a Agariciidae et Pectiniidae", concluding on the one hand that the subdivision between the Echinophyllia zone and the Leptoseris zone described by WELLS (1954) are not clearly distinct in Madagascar. On the other hand, in the same region, some other genera belonging to the Agariciids and Pectiniids (Pachyseris, Oxypora, Pectinia) are also present and locally abundant.

We have few other information on the Echinophyllia and Leptoseris zones in the Indian Ocean and Red Sea except those of GARDINER (1903) in the Maldives, BARNES et al. (1971) in Aldabra, ROSEN (1971) Indian Ocean, LOYA (1972), LOYA \& SLOBODKIN (1971) at Eilat (Red Sea). In the Mascarenes, just as in Madagascar the interpenetration of the two distinct zones defined by Wells is often common but is not a general rule. So, the genera Pachyseris, Oxypora, Echinophyllia first appear in the two preceding and upper zones of the slopes, when the different species of Leptoseris (except L. mycetoseroides) are strickly bound to the volcanic flagstone, chiefly in the middle and lowest horizons. The study of abundance-dominance allows one to distinguish two zones of differents influences: from 25 to $35 \mathrm{~m}$ a "Pachyseris + Echinophyllia zone", beyond $35 \mathrm{~m}$ a "Leptoseris + Pachyseris zone". Nevertheless their respective bathymetrical limits are very variable. For example the first one spreads over to $60 \mathrm{~m}$ in the $\mathrm{N}-\mathrm{E}$ of Mauritius but the second one appears from $25 \mathrm{~m}$ in the same Island

\section{Scleractinian distribution}

A total of 135 species belonging to 58 genera (including the non scleractinian corals: Millepora, Heliopora, Distichopora) are known in the different reef biota of the Mascarene region (FAURE 1976). From this number 98 species belonging to 56 genera appear on the outer slope areas (Table II).

1) Qualitative aspect

a) Large distribution of scleractinian.

Half of the species are tolerant to hydrodynamic activity and light. They are present at once along the outer slope and at the same time in most of the other biota, where they show abundance-dominance and eco-morphs differing according to the local environment: Pocillopora dami-cornis, Stylophora pistillata, S. mordax, Favia speciosa, Goniastrea pectinata, Favites virens, F. pentagona, Acropora hyacinthus, A. reticulata. 


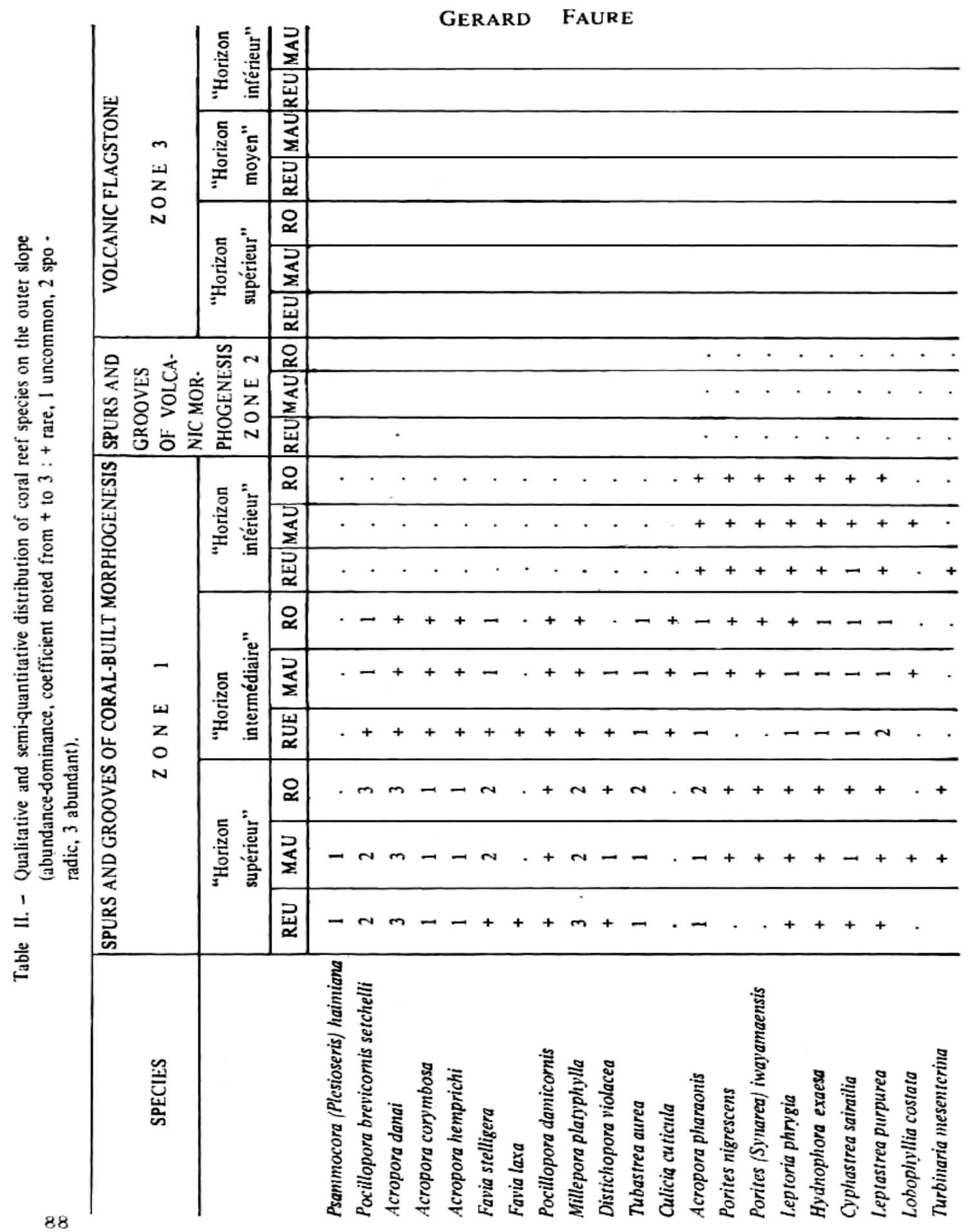




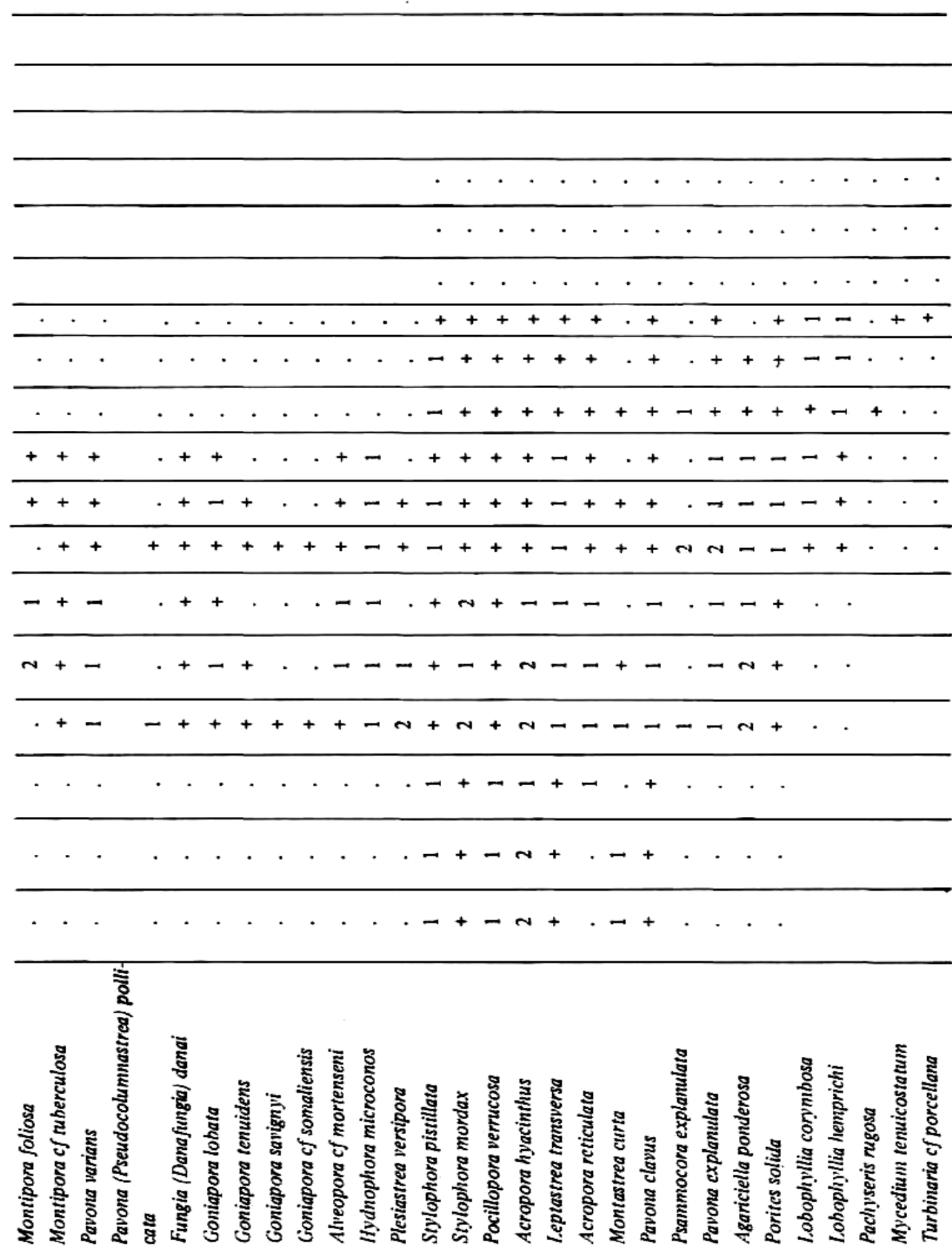




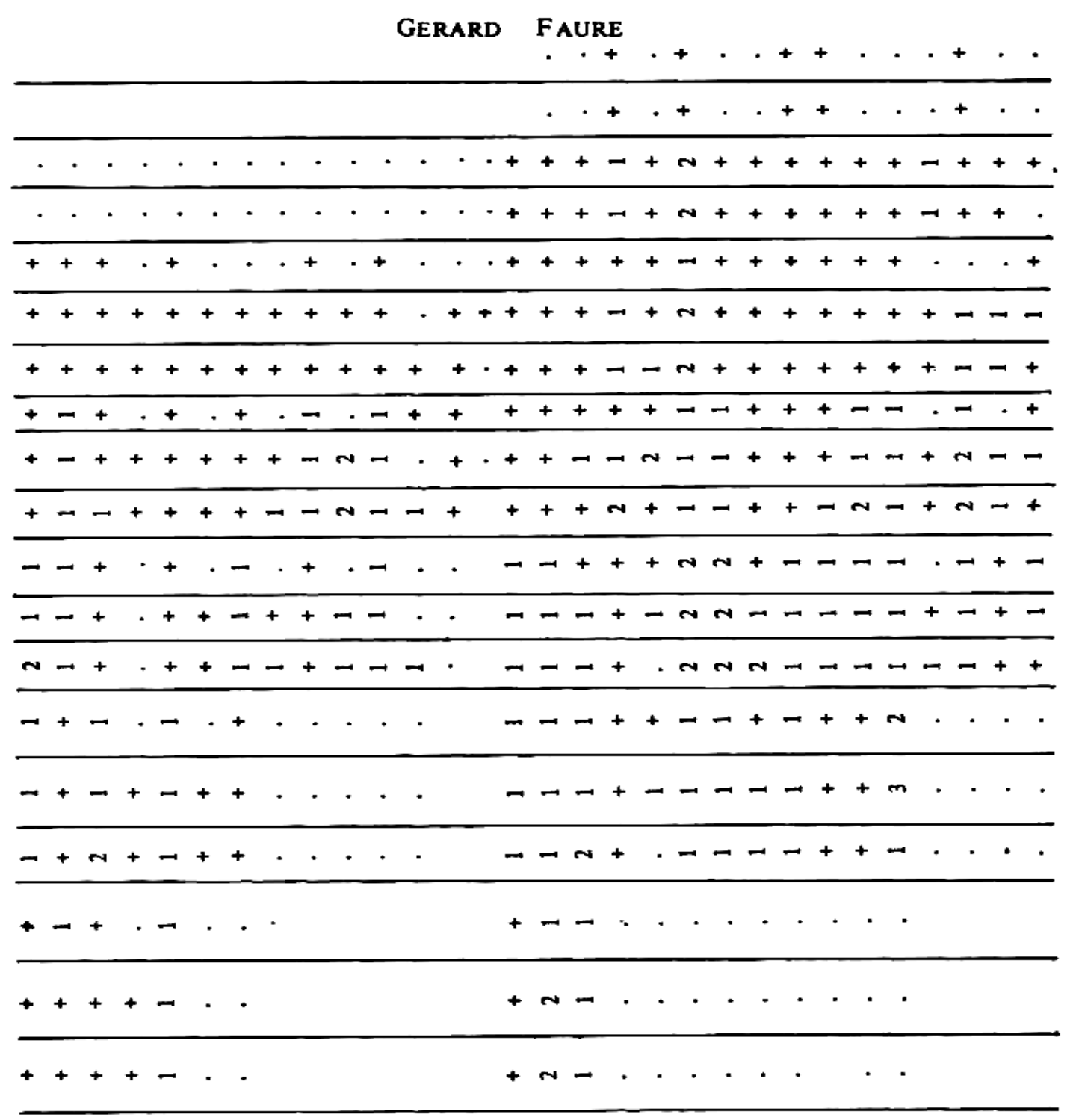

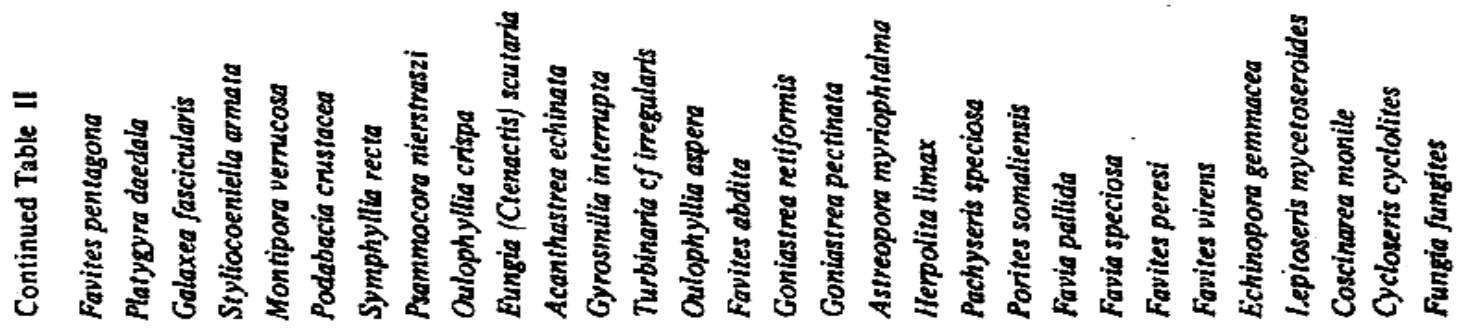


DISTRIBUTION OF CORAL COMMUNITIES

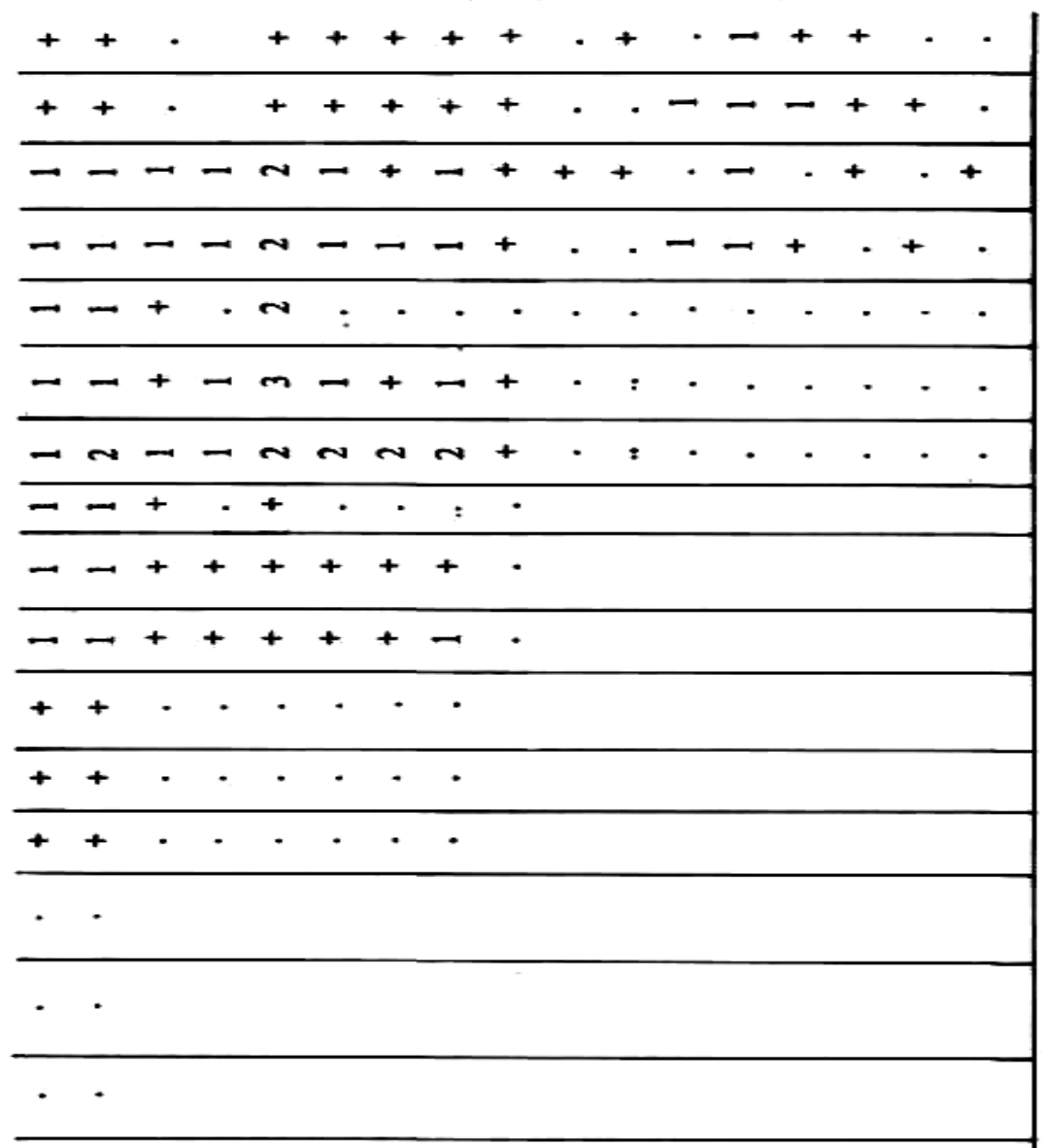

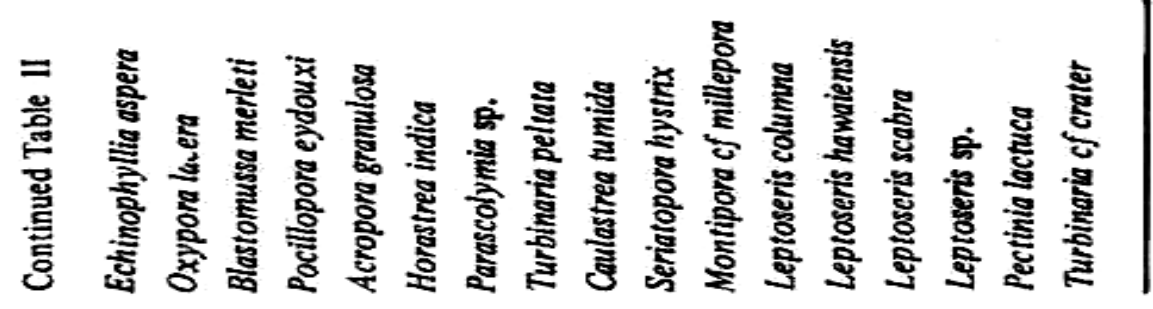




\section{GERARD FAURE}

Leptoria phrygia, Platygyra daedalea, Galaxea fascicularis, Montipora verrucosa ......

b) Characteristic species

A small number of species are characteristic of the outer slope, they are generally restricted to the lower part of the slope according to PICHON (1973) and they belong to two different stocks:

- The first is resctricted to the volcanic flagstone and contains "exclusively characteristic species" ; Leptoseris fragilis, L. columna, L. hawaiensis, Leptoseris sp., Pectinia lactuca, Montipora millepora, and the non hermatypic Tubastrea micrantha.

- The second contains "preferential species" showing a large extension but whose abundance-dominance is maximum for a given biotope:

"Preferential species of the volcanic flagstone": Horastrea indica, Blastumussa merleti, Turbinaria peltata, Parascolymia sp., Echinophyl-lia aspera, Oxypora lacera, Pachyseris speciosa.

"Preferential of the spurs and grooves of volcanic morphogenesis: Lobophyllia hemprichi, Pachyseris rugosa, Turbinaria cf. porcellana Fungia (Ctenactis) scutaria, Oulophyllia crispa, Coscinarea monile.

c) Indicator species

A last group includes species whose abundance-dominance gives an account of water movement ("Rough-water indicators", "Calm water indicators"), of light ("reduced light indicators"), slope ("gradient indicator s"), sedimentary " deposits (' 'sedimentation indicators ").

- "Rough-water indicators" are photophilic species situated in the upper part of the outer slope, the reef front, and outer reef flat: Acropora danai. ... Millepora platyphylla (see zone 1, "horizon superieur").

- Calm water indicators". According to their light requirements they belong to two groups :

"Calm water indicators and strict photophilic species" are limited to the upper part of the slope: Acropora pharaonis, Synarea iwayamaensis, Montipora foliosa.

"Calm water indicators and tolerant photophilic species" ranging from the upper part to the volcanic flagstone: Herpolitha Limax, Gyrosmilia interrupta.

- "Gradient indicators species". They spread out on the wall of spurs and buttresses: Echinopora gemmacea, Pavona explanulata, Leptastrea purpurea, Agariciella ponderosa.

- Sedimentory deposits indicators species : Horastrea indica, Coscinarea monile, Parascolymia sp.

2) Quantitative aspect.

Two main facts give an evident character of relativity to any 
comparative species diversity study. On the one hand, the richness or its opposite the conspicuous poverty of one region chiefly depends on the state of knowledge and degree of investigation in this region. On the other hand there is a disparity in the techniques of sampling and studying used by different authors. Nevertheless the study of the relative fluctuations of the number of species and genera in each biotope and region allows one to have a better knowledge of the role and limits of activity of the primary ecological factors (light, water movement) as well as of importance taken by the secondary local factors (initial topography, slope, sediment deposits, biological competition ....). The study of the propounded profiles * (Fig.2) allows one to bring out general data and to state the local peculiarities which give to each region its originality. Most of the proposed regions with the exception of Maldives and Bikini show generic diversity from 0 to $10 \mathrm{~m}$, the important decrease of light intensity and radiant energy (LOYA 1972, WELLS 1957, JAUBERT \& VASSEUR 1974) is not a limiting factor in coral species abundance in the upper part of the slope. On the contrary the increase in number of species is due to the decrease of wave damage. The increase in coral species abundance goes on between 10 to $20 \mathrm{~m}$ in the Mascarene Archipelago, where maximum diversity is observed at $20 \mathrm{~m}$. This depth has an optimal coral diversity, both with respect to wave action and light conditions. Yet decreased light action seems to have as consequences: decrease of coral coverage $(\leq 50 \%)$, and rate of uptake calcium (FAURE \& PICHON 1976). In the same way, the results of Eilat and Fanning Island are very similar to those of Madagascar and the Mascarene region, except a low abundance in a discontinuity between $13-17 \mathrm{~m}$. This relatively low abundance of coral species in the discontinuity is explained by Loya in Eilat not as the result of light decrease, but mainly as a result of the sedimentation effect (local secondary factor). At the same depths, in the Maldives region the number of genera is steady then grows between $15-20 \mathrm{~m}$, where a secondary maximum is observed. Only the Bikini example (sharp linear decrease of species from 0 to $20 \mathrm{~m}$ ) seems to be more a part of the other profiles. The depth from which the light intensity starts to have critical effect on the specific diversity differs according to the different regions: Mascarene and Maldives $20-25 \mathrm{~m}$, Madagascar $22-25 \mathrm{~m}$, Eilat and Fanning Island $30 \mathrm{~m}$, Jamaica ( LOYA 1972) $40 \mathrm{~m}$.

In Fanning Island however MARAGOS (1974) describes a Lobophyllia costata, Sarcophyton sp. zone between $20-25 \mathrm{~m}$, where "these colonies can exclude other corals and reduce diversity". Such observations were made in the same way in the Mascarene region where locally the low abundance of coral species may be more the result of biological competition (see algae

* The choice of the regions was settled on the basis of geographical considerations as well as on actual environmental conditions and diversity of state knowledge. 
GERARD FAURE

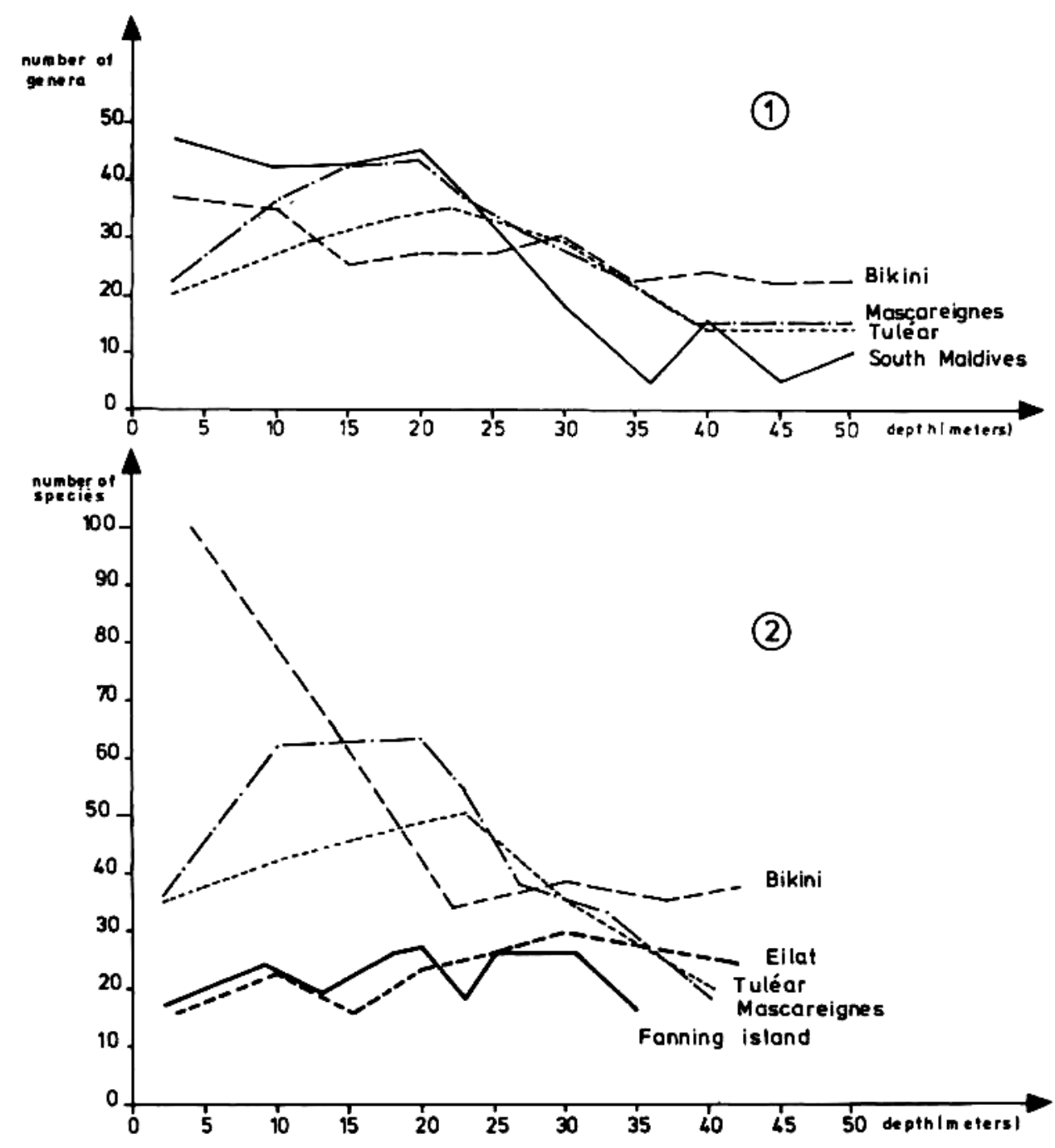

- THE VARIATION OF CORAL DIVERSITY, 1 GENERA, 2 SPECIES, WITH THE DEPTH FOR SOME INDOPACIFIC REGIONS :

Bikini (Wells 1954, Rosen 1975)

South Maldives (Rosen 1975)

Eilat * (Loya and Slobodkin 1971, Loya 1972)

Tulear Madagascar (Pichon 1973)

Fanning island** (Maragos 1974)

Mascareignes (present paper)

NB : * (average number of species per transect)

** (species richness for a group of 10 quadrats)

Higure 2. 


\section{DISTRIBUTION OF CORAL COMMUNITIES}

and alcyonarian facies), than an effect of decreased light intensity. On the contrary in Bikini the sharp decrease observed from 0 to $20-25 \mathrm{~m}$ stops at this depth, then non-surface hermatypic species appear. Below this zone, according to the local visibility the decrease of coral activity: number of colonies, coral coverage varies with the depth. Only the more specialized species, number of colonies, coral coverage varies with the depth. Only the more specialized species (hemisciaphilic species: PICHON 1973) can live well in such biota, where they compete with other communities well adjusted to reduced light, or having a restricted distribution according to local sedimentation effects. Thus in brief: The influence of hydrodyna-mic factors and light intensity appears mainly near limit values (threshold of activity) in all areas where the scleractinian communities have a reduced vitality (weak in coverage percentage and specific diversity). When the optimal light and water movement join forces coverage and coral specific diversity are raised. Yet both high coral coverage and abundant specific diversity do not obligatorily go together. A large abundance-dominance of a small group of species can overspread the substrate and have a detrimental action on or exclude other species. The conclusions of MARAGOS (1974), PICHON (1973), LOYA (1972) are the same. The knowledge of the action of local factors is very important in allowing one to understand local disturbances and discontinuities in coral communities.

\section{REFERENCES}

BARnes, J., D.J. Bellamy, D.J. Jones, BA . WhitTon, E.A. DREW, L. KenYON, J.N. LYTHGOE, and B.R. ROSEN 1971. Morphology and ecology of the reef front of Alda-bra. In D.R. STODDART, ed., Regional variation in Indian Ocean Coral reefs. Symp. Zool. Soc. Lond. $28: 87-114$.

BATTISTINI, R. et allii, 1975. Elements de terminologie recifale indo-pacifique. Tethys 7 (1) : 1 111 .

CheVAlier, J.P., M. BenizOT, J.L. MOUGIN, Y. PleSSIS, and B. SAlVAT 1969. Etude geomorphologique et bionomique de l'atoll de Mururoa (Tuamotu). Cahiers du pacifique, 12 : $1-144$.

CLAUSADE, M., N. GRAVIER, J. PICARD, M. PICHON, M.L. ROMAN, B. THOMASSIN, P. VASSEUR, M. VIVltN, and P. WEYDERT 1971. Morphologie des recifs coralliens de la region de Tulear (Madagascar) : Elements de terminologie recifale. Tethys, Suppl. 2:74 PP.

FAURE, G. 1974. Morphology and bionomy of the coral reef discontinuities in Rodriguez Island (Mascarene Archipelago, Indian Ocean), pp 161 - 181, in: Cameron / M., Campbell

M.M., et allii., Proceeding of the second international Coral reef Symposium, 2, Great Barrier Reef Committee, Brisbane : 753 pp.

FAURE, G. 1975. Etude comparative des recifs coralliens de I'archipel des Mascareignes (Ocean Indien). Bull. Mauritius Inst., VIII, I : 1 - 25.

FAURE, G. 1976. Annotated check list of Scleractinian corals of the Mascarene Archipelago. Atoll research (under press). 


\section{GERARD FAURE}

FAURE, G., and L. MONTAGGIONI 1970. Le re'cif de St-Pierre de la Reunion (Ocean indien) : Geomorphologie et repartition des peuplements. Rec. Trav. Stat. Mar. Endoume, Hors ser., suppl. $10: 271: 284$.

FAURE, G., and L. MONTAGGIONI 1971a. Les recifs coralliens sous le vent de l'lle Maurice (Archipel des Mascareignes, Ocean Indien) : Morphologie et bionomie de la pente externe $C R$. Acad. Sci. Paris, 273: 1914 - 1916.

FAURE, G., and L. MONTAGGIONI 1971b. The coral reefs of Rodriquez Island (Mascarene Archipelago, Indian Ocean): Geomorphology and associated invertebrate communities. Proc. Symp. Indian ocean and adjacent seas. Jan. 1971, Cochin (under press).

FAURE, G., and L. MONTAGGIONI 1975. Les recifs coralliens au vent de Tile Maurice (Archipel des Mascareignes, Ocean Indien): Morphologie et bionomie de la pente externe. Mar. Geol. (under press).

FAURE, G., and M. PICHON 1976. Description de Favites peresi, nouvelle espece de Scleractiniare hermatypique de l'Ocean indien. (under press).

GARDINER, J.S. 1903. The Maldive and Laccadive groups, with notes on other coral formations in the Indian Ocean. Fauna and Geogr. Maldive and Laccadive Archipelagoes I : 146-183, 313-346,376-423.

GOREAU, T.F. 1959. The ecology of Jamaica coral reefs (species Composition and zonation) Ecology, 40, (1) : 67 - 90.

GOREAU, T.F. and W.B. HARTMAN 1963. Boring sponges as controlling factors in the formation and maintenance of coral reefs. Publ. Amer. Assoc. Advanc. Sci. IS : 25 - 54.

JAUBERT, J.M., and P. VASSEUR 1974. Light measurement: Duration aspect and the distribution of benthic organisms in an Indian coral reef (Tulear, Madagascar), pp 127 - 141, in : Cameron A.M., Campbell M.M., et allii, Proceedings of the second international coral reef symposium, 2, Great Barrier Reef Committee, Brisbane : $753 \mathrm{pp}$.

LABOREL, J. 1967. Les peuplements de Madreporaires des cotes tropicales du Bresil. These Doc. Sci. nonpubl. Univ. Marseille, A.O. 1856:1-313.

LEWIS, J.B. 1960. The coral reefs and coral communities of Barbados, W.I. Can. J. Zool. 38 $: 1133-1145$.

LOGAN, B.W. 1969. Coral reefs and banks, Yucatan shelf Mexico (Yucatan Reef Unit.) in : Carbonate sediments and reefs, Yucatan shelf, Mexico (by B.W. Logan, J.L. Harding, W.M. Ahr, J.D. Williams and R.G. Snead) : 129 - 198 Mem. Am. Ass. Petrol.

LOYA, Y. 1972. Community structure and species diversity of hermatypic corals at Eilat, Red Sea. Mar. Biol, 13, (2) : 100 - 123.

LOYA, Y., and L.B. SLOBODKIN 1971. The coral reefs of Eilat (Gulf of Eilat, Red Sea) in D.R. STODDART, ed., Regional variation in Indian Ocean Coral reefs. Symp. Zool. Soc. Lond. 28 : 117 - 139. MARAGOS, 1974. Coral communities on a seeward reef slope, Fanning Island. Pacific sciences,28 (3) : 257 -278.

MONTAGGIONI, L. 1970a. Repartition et zonation geomorphologiques des structures recifales de I'lle de la Reunion (Ocean Indien). CR. Acad. Sci. Paris, D, 270 : 663 - 665.

MONTAGGIONI, L. 1970b. Essai de chronologie relative des episodes recifaux a Tile de la Reunion (Ocean Indien); leur incidence sur la morphologie recifale actuelle. CR. Acad. Sci. Paris, D, $270: 1869$ - 1871.

MONTAGGIONI, L. 1972. Essai de chronologie relative des stationnements marins quaternaries a l'lle Maurice (Archipel des Mascareignes, Ocean Indien). CR. Acad. Sci. Paris, D, 274 : 2936 - 2939.

MONTAGGIONI, L. $1974 . \quad$ Coral reefs and Quaternary shore-lines in the Mascarene Archipelago (Indian Ocean), pp 579-593 in : Cameron A.M., Campbell M.M., et allii, Symposium, 2, Great Barrier Reef Committee, Brisbane : 753 pp.

PICHON, M. 1964. Contribution a Tetude de la repartion des Madreporaires sur le recif de Tulear 


\section{DISTRIBUTION OF CORAL COMMUNITIES}

(Madagascar). Rec. Trav. Stat. Mar. Endoume, hors ser., suppl 2 : 79-203.

PICHON, M. 1967. Caracteres generaux des peuplements benthiques des recifs et lagons de Pile Maurice. Cahiers ORSTOM, Oceanogr. V, $4: 31-45$.

PICHON, M. 1973. Recherches sur les peuplements a dominance d'anthozoaires dans les recifs co-ralliens de Tule'ar (Madagascar). These Doc. Sci. non publ. Univ. Marseille, A.O. $9255: 1$-416.

RIGBY, J.K., and W.G. MC INTIRE 1966. The Isla de Lobos and associated reefs, Veracruz, Mexico. Brigham Young Univ. Geol. Stud., $13: 3-46$.

ROBERT, R. 1974.Morphologie littorale de 1Tle de la Reunion. Collect. Trav. Centre Universitaire de la Reunion : $82 \mathrm{pp}$.

ROOS, P.J. 1964 The distribution of reef corals in CuraCao. Stud. Fauna CuraCao 20 : 1 - 51.

ROSEN, B.R. 1971. The distribution of reef coral genera in the Indian ocean. In D.R. STODDART, ed. Regional variation in Indian Ocean coral reefs. Symp. Zool. Soc. Lond. 28:263-299.

ROSEN, B.R. 1975. The distribution of reef corals. Rep. Underwater Ass. Vol 1 (NS) : 1 - 16.

SCATTERDAY, J.W. 1974. Reefs and associated coral assemblages of Bonaire, Netherlands Antilles and their bearing on Pleistocene and recent reef models, pp 85-106 in : Cameron A.M., Campbell M.M., et allii, Proceedings of the second international coral reef symposium, 2, Great Barrier Reef Commitee : $753 \mathrm{pp}$.

THOMASSIN, B. 1971. Les fades d'epifaune et d'epiflore des biotopes sedimentaires des formations coralliennes dans la region de Tulear (Sud-Quest de Madagascar) in Dr STODDART, ed. Regional variation in Indian Ocean Coral reefs. Symp. Zool. Soc. Lond. $28: 371-396$.

WELLS, J.W. 1954. Bikini and nearby atolls : (2) oceanography (biologic). Recent Corals of the Marshall Islands. Prof. Pap. U.S. Geol. Surv. 260 (I) : 385 - 486.

WELLS, J.W. 1957. Coral reefs. In Treatise on marine ecology and paleoecology I, Ecology. Hedgpeth, J.W., ed. Mem. Geol. Soc. Am. 67 (1): 609 - 631.

WEYDERT, P. 1974. Morphologic et sedimentologie de la pente externe de la partie nord du grand recif de Tulear (S.O. de Madagascar). Nature et repartition des elements organogenes libres. Mar. Geol., 17 : 299 - 337. 